\title{
Hubungan Antara Komunikasi Interpersonal Pasutri dengan Keharmonisan dalam Pernikahan
}

\author{
Nyoman Riana Dewi dan Hilda Sudhana \\ Program Studi Psikologi, Fakultas Kedokteran, Universitas Udayana \\ nyomanrianadewi@ymail.com
}

\begin{abstract}
Abstrak
Keharmonisan pernikahan akan sulit terwujud tanpa adanya hubungan interpersonal yang baik antara suami dan istri. Dalam menciptakan hubungan interpersonal yang baik perlu adanya komunikasi yang efektif sehingga dapat menghindari diri dari situasi yang dapat merusak hubungan yang menyebabkan pernikahan menjadi tidak harmonis. Penelitian ini bertujuan untuk mengetahui hubungan antara komunikasi interpersonal pasangan suami istri dengan keharmonisan dalam pernikahan.

Penelitian ini merupakan penelitian kuantitatif dengan menggunakan metode korelasi product moment. Teknik pengambilan sampel yang digunakan adalah teknik Simple Random Sampling, dengan jumlah subjek 110 orang. Alat ukur dalam penelitian ini adalah skala komunikasi interpersonal dan skala keharmonisan pernikahan. Berdasarkan hasil penelitian diperoleh nilai korelasi ( $\mathrm{r}$ ) sebesar 0,649 dengan probabilitas sebesar 0,000 ( $\mathrm{p}<0,05)$, sehingga menunjukkan bahwa terdapat hubungan yang postif antara komunikasi interpersonal pasutri dengan keharmonisan dalam pernikahan. Adapun besar sumbangan efektif yang diberikan komunikasi interpersonal pasutri terhadap keharmonisan pernikahan sebesar $42,2 \%$ dan sisanya sebesar $57,8 \%$ dipengaruhi oleh faktor-faktor lain yang tidak diteliti dalam penelitian ini.
\end{abstract}

Kata kunci : Komunikasi interpersonal pasutri, keharmonisan dalam pernikahan

\begin{abstract}
Marital harmony will be difficult to achieve without a good interpersonal relationship between husband and wife. In creating a good interpersonal relationship needs effective communication so as to prevent yourself from situation that could damage the relationship and can lead to not harmonious marriage. This study aimed to determine the relationship between interpersonal communication with marital harmony.

This study is a quantitative research that used a product moment correlation. The sampling technique used is the technique simple random sampling, with 110 subjects. The scale used in this research are scale interpersonal communication and scale marital harmony. Based on the results obtained correlation values (r) of 0,649 with probabilities of $0,000(\mathrm{p}<0,05)$. The result from test data analysis is that there is a positive and significant correlation between interpersonal communication with marital harmony. The effective contribution to interpersonal communication with marital harmony is $42,2 \%$ and the others are $57,8 \%$ is influenced by other factors not examined in this study.
\end{abstract}

Keywords: Interpersonal communication, marriage harmony 


\section{N. R. DEWI DAN H.SUDHANA}

\section{LATAR BELAKANG}

Perkawinan merupakan salah satu kejadian penting yang akan dihadapi oleh setiap manusia dalam perjalanan hidup. Hal tersebut terbukti dari hasil penelitian yang menunjukkan bahwa sembilan dari sepuluh individu usia dewasa awal pada akhirnya akan melakukan perkawinan Atwater (dalam Vembry, 2012). Hasil penelitian tersebut tidak mengherankan karena melakukan perkawinan dan belajar hidup bersama pasangan dalam ikatan perkawinan merupakan tugas perkembangan dewasa muda Hurlock (dalam Vembry, 2012). Perkawinan yang dianggap sah dalam Undang-Undang Republik Indonesia Nomor 1/1974 yaitu, apabila sepasang pria dan wanita telah melangsungkan suatu pernikahan, seperti yang telah dinyatakan dalam bab I, pasal 1 bahwa "Pernikahan adalah ikatan lahir batin antara seorang pria dengan seorang wanita sebagai suami istri dengan tujuan membentuk keluarga yang bahagia dan kekal berdasarkan Ketuhanan Yang Maha Esa". Selain itu di dalam Undang-Undang No. 1 tahun 1974, pasal 7 mensyaratkan bahwa pernikahan dapat dilakukan jika seseorang telah berusia 21 tahun dan telah memiliki kematangan psikologis.

Pernikahan adalah suatu kewajiban bagi setiap individu seperti yang sudah ditetapkan dalam setiap ajaran agama. Dalam setiap ajaran agama pernikahan memiliki makna yang suci atau sakral, yang pada dasarnya bertujuan untuk membentuk keluarga yang bahagia. Dewasa ini pernikahan telah luntur dari makna yang suci atau sakral akibat pergeseran nilai-nilai dalam hidup sehingga tidak jarang suatu pernikahan yang akhirnya berujung pada perceraian. Tingginya angka perceraian di Indonesia terbukti dari data yang dihimpun Dirjen Badan Peradilan Agama Mahkamah Agung RI, di tahun 2010 lembaga ini mencatat 285.184 kasus perceraian, dimana angka tersebut menunjukkan angka perceraian yang tertinggi sejak 5 tahun terakhir (Saputra, 2011).

Di Provinsi Bali, khususnya di kota Denpasar angka perceraian yang terjadi dalam 5 tahun terakhir ini, tidak jauh berbeda dengan angka perceraian yang terjadi di Provinsi Jawa Timur. Data angka perceraian yang tercatat di Pengadilan Negeri Denpasar mengalami peningkatan setiap tahunnya, dimana yang tercatat pada tahun 2008 sebanyak 336 kasus, tahun 2009 sebanyak 394 kasus, tahun 2010 sebanyak 442 kasus dan tahun 2011 sebanyak 535 kasus yang masuk ke pengadilan. Koordinator bagian Perdata Pengadilan Negeri Denpasar (2012), mengatakan bahwa sebagian besar istri yang menggugat cerai suaminya. Perceraian yang terjadi, paling banyak dipengaruhi oleh adanya pihak ketiga dalam rumah tangga sehingga mengakibatkan ketidakcocokan, pertengkaran suami dan istri, ketidakharmonisan yang berujung pada perceraian.

Dalam membangun suatu pernikahan yang harmonis, ternyata tidak semudah seperti yang dibayangkan. Tingginya angka perceraian yang terjadi sebagai salah satu bukti bahwa tidak semua pernikahan berjalan dengan lancar seperti yang diharapkan oleh setiap pasangan suami istri. Surya (2001), mengatakan bahwa keharmonisan merupakan kondisi hubungan interpersonal yang melandasi keluarga bahagia. Keharmonisan keluarga merupakan suatu perwujudan kondisi kualitas hubungan interpersonal baik inter maupun antarkeluarga. Hubungan interpersonal merupakan awal dari keharmonisan. Hal ini mengandung arti bahwa keharmonisan sulit terwujud tanpa adanya hubungan interpersonal, baik dalam keluarga maupun antar keluarga. Suasana hubungan yang baik dapat terwujud dalam suasana yang hangat, penuh pengertian, penuh kasih sayang satu dengan lainnya sehingga dapat menimbulkan suasana yang akrab dan ceria. Dasar terciptanya hubungan ini adalah terciptanya komunikasi yang efektif, sehingga untuk membentuk suatu pernikahan yang harmonis antara suami dan istri perlu adanya hubungan interpersonal yang baik antara suami dan istri dengan menciptakan komunikasi yang efektif.

Dalam sebuah pernikahan seorang pria sebagai suami dan seorang wanita sebagai istri memiliki hak dan kewajiban masing-masing, dimana suami memiliki kewajiban untuk memberi nafkah bagi keluarganya sedangkan istri memiliki kewajiban untuk mengatur dan mengurus rumah tangga. Seiring dengan pesatnya pertumbuhan dan perkembangan ekonomi yang terjadi dalam beberapa dekade ini membuat tuntutan sosial ekonomi dalam keluarga semakin tinggi. Hal ini yang sering mendorong wanita sebagai istri untuk ikut serta dalam pemenuhan kebutuhan rumah tangga dengan turut bekerja. Peran wanita adalah sebagai istri, sebagai ibu dan sebagai pengurus rumah tangga, akan tetapi seiring dengan perkembangan zaman dan tuntutan ekonomi, banyak wanita yang turut bekerja dengan ruang lingkup di dalam maupun di luar rumah dan berbagai faktor yang melatarbelakanginya Munandar (dalam Pertiwi, 2006).

Nugroho (2007) mengatakan bahwa dampak dari keterlibatan wanita bekerja adalah terjadinya konflik antara kebutuhan untuk pengembangan diri dalam karir dengan nilainilai tradisional yang melekat pada wanita yaitu bertanggung jawab dalam tugas-tugas rumah. Konflik antara pekerjaan dan keluarga hadir pada saat individu harus menampilkan multi peran yaitu pekerjaan, pasangan dan sebagai orang tua Senecal (dalam Nugroho, 2007). Kewajiban utama seorang istri yaitu mengurus rumah tangga seringkali menjadi dilema bagi seorang istri karena harus melakukan pekerjaan tersebut secara beriringan (Gustin, 2009). Hal ini menyebabkan banyaknya masalah, karena secara otomatis istri akan sangat sibuk menjalani kedua rutinitas tersebut sehingga, dimana kesibukan membuat mereka tidak memiliki cukup waktu untuk bertemu, saling berbagi dan berkomunikasi. Kurangnya komunikasi antara suami dan istri dapat menimbulkan rasa tidak percaya dan pikiran-pikiran negatif sehingga sering terjadi kesalah 


\section{N. R. DEWI DAN H.SUDHANA}

pahaman yang dapat menimbulkan konflik. Konflik yang berlarut-larut membuat hubungan suami istri menjadi renggang dan menyebabkan komunikasi menjadi tidak efektif sehingga pernikahan menjadi tidak harmonis (Surya, 2001).

Surya (2001) mengatakan bahwa tidak jarang wanita yang bekerja cukup sukses dalam membina rumah tangga yang harmonis, dengan karir yang dimiliki istri dapat menunjang kebahagiaan dan kemajuan bagi rumah tangganya, karena secara ekonomi dengan bekerja dapat membantu kelangsungan hidup keluarga secara finansial. Secara sosial, kaum wanita dapat mengabdikan dirinya untuk kepentingan sosial, dimana lingkup pergaulan sosial menjadi lebih luas. Secara psikologis, dengan bekerja wanita dapat memperoleh kepuasan pribadi yang dapat menunjang kebahagian. Selanjutnya Surya (2001) menjelaskan bahwa salah satu cara yang dapat dilakukan wanita yang bekerja atau berkarir untuk bisa sukses dalam membangun rumah tangga yang harmonis adalah dengan melakukan penyesuaian antara diri dengan pekerjaan yang disertai oleh dukungan dari suami dan anggota keluarga untuk bisa menjaga keseimbangan antara pekerjaan dan urusan rumah tangga. Dukungan tersebut dapat dikembangkan melalui komunikasi interpersonal yang efektif antara suami dan istri.

Komunikasi yang sering digunakan suami istri dalam berinteraksi adalah komunikasi interpersonal. Komunikasi interpersonal merupakan komunikasi antara orang-orang secara tatap muka, yang memungkinkan setiap pesertanya menangkap reaksi orang lain secara langsung, baik secara verbal maupun nonverbal (Mulyana, 2008). Salah satu tipe komunikasi interpersonal yang digunakan dalam berinteraksi pada pasangan suami istri adalah yang bersifat diadik yaitu melalui komunikasi dalam situasi yang lebih intim, lebih dalam dan personal. Komunikasi interpersonal yang terjalin antar suami istri mempunyai peranan yang penting untuk menjaga kelangsungan berumah tangga. Sastropoetro (1986) menyatakan bahwa dengan komunikasi yang baik berarti memelihara hubungan yang telah terjalin sehingga menghindari diri dari situasi yang dapat merusak hubungan. Komunikasi yang baik adalah komunikasi yang efektif, yang mempunyai ciri saling terbuka, empati, saling mendukung, sikap positif dan kesetaraan (Devito, 1997). Hasil penelitian Defrain dan Olson menyimpulkan bahwa $90 \%$ pasangan suami istri merasa bahagia dalam hubungannya dengan berkomunikasi satu dengan lainnya sehingga mereka dapat merasakan dan mengerti keinginan dan perasaan pasangan, dan apabila terdapat suatu perbedaan atau masalah dapat diselesaikan dengan saling berkomunikasi (dalam Pratiwi, 2006).

Berdasarkan uraian diatas, peneliti ingin mengetahui apakah ada hubungan positif antara komunikasi interpersonal pasangan suami istri dengan keharmonisan dalam pernikahan. Peneliti mengharapkan penelitian ini dapat memberikan informasi pada bidang psikologi sosial, khususnya mengenai komunikasi interpersonal pasutri dan psikologi perkembangan mengenai dewasa awal tentang keharmonisan pernikahan. Manfaat praktis dari penelitian ini yaitu sebagai bahan masukan bagi orang-orang yang akan menempuh bahtera rumah tangga maupun yang sudah membentuk rumah tangga, diharapkan melalui penelitian ini pasangan suami istri dapat mempertahankan hubungan rumah tangga yang harmonis melalui komunikasi interpersonal.

\section{METODE}

\section{Variabel dan definisi operasional}

Penelitian ini menggunakan penelitian kuantitatif dengan menggunakan variabel bebas dan variabel terikat. Variabel bebas merupakan variabel yang mempengaruhi atau yang menjadi sebab perubahan variabel terikat, dan variabel terikat adalah variabel yang dipengaruhi atau yang menjadi akibat, karena adanya variabel bebas (Sugiyono, 2012). Variabel bebas pada penelitian ini yaitu komunikasi interpersonal dan variabel terikat yaitu keharmonisan pernikahan.

Definisi operasional dari variabel komunikasi interpersonal adalah proses pengiriman dan penerimaan pesan antara dua orang atau kelompok kecil dengan feed back, baik secara langsung maupun tidak langsung. Komunikasi interpersonal diungkap dengan skala Likert yang disusun berdasarkan aspek-aspek komunikasi interpersonal yang dikemukakan oleh Devito yang diadaptasi dari penelitian (Hidayah, 2007) yaitu lima sikap positif yang perlu dipertimbangkan dalam melakukan komunikasi interpersonal antara lain keterbukaan, empati, sikap mendukung, sikap positif, dan kesetaraan.

Keharmonisan pernikahan adalah keadaan yang sinergis antara suami dan istri dengan terciptanya iklim saling menghormati, saling menerima, saling menghargai, saling mempercayai, dan saling mencintai antar pasangan sehingga dapat menjalankan peran-perannya dengan penuh kematangan sikap, serta dapat melalui kehidupan dengan penuh keefektifan dan kepuasan batin. Keharmonisan pernikahan diungkap dengan skala Likert yang disusun berdasarkan aspek-aspek keharmonisan pernikahan yang dikemukakan oleh Daradjat yang diadaptasi dari penelitian (Hisbullah, 2007) yang terdiri dari saling menghormati, saling menerima, saling menghargai, saling mempercayai, dan saling mencintai.

\section{Responden}

Populasi adalah wilayah generalisasi yang terdiri atas objek atau subjek yang mempunyai kualitas dan karakteristik tertentu yang ditetapkan oleh peneliti untuk dipelajari dan kemudian ditarik kesimpulannya (Sugiyono, 2012). Populasi dalam penelitian ini adalah istri yang bekerja yang berada di 
Kota Denpasar, Provinsi Bali. Sampel adalah bagian dari jumlah dan karakteristik yang dimiliki oleh populasi. Sampel yang diambil dari populasi harus benar-benar representatif atau mewakili (Sugiyono, 2012). Jumlah sampel yang digunakan dalam penelitian ini berdasarkan rumus yang dikemukakan oleh (Higgins, Kleinbaum, \& Miller, 1985) diperoleh jumlah sampel yaitu sebanyak 110 subjek.

Metode pengambilan sampel yang digunakan dalam penelitian ini adalah metode simple random sampling yaitu pengambilan sampel dari populasi yang homogen, yang dilakukan secara acak tanpa memperhatikan strata yang ada dalam populasi itu (Sugiyono, 2012). Dalam pengambilan sampel peneliti menentukan beberapa kriteria inklusi subjek dalam penelitian, antara lain:

a. Istri yang bekerja (pasangan suami istri sama-sama bekerja)

Nugroho (2007) mengatakan bahwa dampak dari keterlibatan wanita bekerja adalah terjadinya konflik antara kebutuhan untuk pengembangan diri dalam karir dengan nilainilai tradisional yang melekat pada wanita yaitu bertanggung jawab dalam tugas-tugas rumah. Selain itu, Gustin (2009) menyebutkan bahwa kewajiban utama seorang istri yaitu mengurus rumah tangga seringkali menjadi dilema bagi seorang istri karena harus melakukan pekerjaan tersebut secara beriringan. Hal ini menyebabkan banyaknya masalah, karena secara otomatis istri akan sangat sibuk menjalani kedua rutinitas tersebut sehingga jalinan komunikasi dalam keluarga jarang terjadi. Pada pasangan suami istri yang sama-sama bekerja, biasanya kesibukan membuat mereka tidak memiliki cukup waktu untuk bertemu, saling berbagi dan berkomunikasi. Kurangnya komunikasi antara suami dan istri dapat menimbulkan rasa tidak percaya dan pikiran-pikiran negatif sehingga sering terjadi kesalah pahaman yang dapat menimbulkan konflik.

b. Berusia 21-35 tahun atau dewasa awal

Di Indonesia, syarat untuk setiap orang dapat melakukan pernikahan tertera dalam Undang-Undang No. 1 tahun 1974, dalam pasal 7 yang mensyaratkan bahwa pernikahan dapat dilakukan jika seseorang telah berusia 21 tahun dan telah memiliki kematangan psikologis.

Menurut teori perkembangan yang dikemukakan oleh Papalia (dalam Murcahya, 2010) masa usia menikah adalah usia dewasa awal yaitu antara 20-40 tahun. Hal ini dapat diartikan sebagaimana fungsi perkembangan dewasa awal untuk memasuki dunia pernikahan dan dan membina bahtera rumah tangga. Hal ini sesuai dengan teori yang dikemukakan oleh Hurlock (dalam Murcahya, 2010) yang menyatakan bahwa tugas perkembangan yang menjadi karakteristik masa dewasa.

Selain itu, perlu dipertimbangkan dari segi medis dan psikologisnya awal adalah mulai memilih pasangan hidup dan mulai bekerja. Untuk perempuan, idealnya menikah di usia
20-35 tahun. Secara medis, pada umur 20 tahun ke atas, organ reproduksi perempuan sudah siap mengandung dan melahirkan, sedangkan pada usia 35 tahun mulai terjadi proses degeneratif. Secara psikologis usia 20 tahun juga mulai matang, bisa mempertimbangkan secara emosional dan nalar.

c. Usia pernikahan 0-5 tahun

Tahun-tahun pertama pernikahan merupakan masa rawan, yang disebut sebagai era kritis karena pengalaman bersama belum banyak. Clinebell \& Clinebell (dalam Suryanto, 2006) mengatakan bahwa periode awal pernikahan merupakan masa penyesuaian diri, dan krisis muncul saat pertama kali memasuki jenjang pernikahan. Selanjutnya Hurlock (dalam Wardhani, 2012) menyebutkan bahwa pada masa penyesuaian diri, terkadang pasangan suami istri sering mengalami suatu permasalahan yang dapat menimbulkan ketegangan emosi.

d. Bertempat tinggal di Kota Denpasar, Provinsi Bali

Menurut data yang diperoleh dari Pengadilan Negeri Denpasar, kasus perceraian yang tercatat terus meningkat setiap tahunnya, sehingga peneliti memilih untuk mengambil subjek penelitian ini yaitu individu yang bertempat tinggal di kota Denpasar.

\section{Tempat Penelitian}

Responden dalam penelitian ini disesuaikan dengan kriteria inklusi dalam penelitian yaitu, istri yang bekerja, berusia 21-35 tahun atau dewasa awal, usia pernikahan 0-5 tahun, dan berada di Denpasar. Alasan peneliti memilih kawasan Denpasar sebagai tempat penelitian ini, karena berdasarkan data yang diperoleh dari Pengadilan Negeri Denpasar, di kota Denpasar kasus perceraian yang tercatat terus mengalami peningkatan setiap tahunnya. Berdasarkan teknik simple random sampling, maka peneliti menyebarkan kuesioner kepada orang-orang di sekitar lingkungan tempat tinggal peneliti seperti diberikan kepada teman atau kenalan, saudara, tetangga, dan beberapa pegawai yang ada di Fakultas Kedoteran Universitas Udayana, yang telah sesuai dengan kriteria inklusi yang telah ditetapkan oleh peneliti.

\section{Alat ukur}

Skala komunikasi interpersonal yang dikemukakan oleh Devito yang kemudian diadaptasi dari penelitian (Hidayah, 2007). Skala itu memiliki jumlah 47 item yang diadaptasi dan dimodifikasi oleh peneliti sehingga berjumlah 45 item. Skala kedua yaitu keharmonisan pernikahan yang dikemukakan oleh Daradjat yang kemudian diadaptasi dari penelitian (Hisbullah, 2007), dengan skala yang berjumlah 30 item. Setelah diuji validitas dan reliabilitasnya, item skala komunikasi interpersonal menjadi 26 item dan skala keharmonisan pernikahan menjadi 18 item. 


\section{Metode pengumpulan data}

Metode pengumpulan data yang digunakan dalam penelitian ini adalah metode kuesioner yaitu suatu cara pengumpulan data dengan menyebarkan daftar pertanyaan kepada responden dengan harapan mereka akan memberikan respon terhadap daftar pertanyaan tersebut (Husein, 2002). Kuesioner tersebut mengandung pertanyaan yang berguna untuk melihat sejauh mana responden setuju atau tidak setuju dengan pertanyaan tersebut.

Terdapat dua kuesioner yang digunakan dalam penelitian ini, yaitu kuesioner komunikasi interpersonal dan kuesioner keharmonisan pernikahan. Kuesioner untuk mengukur komunikasi interpersonal dan keharmonisan pernikahan terdiri dari empat pilihan jawaban, yakni 'sangat tidak setuju', 'tidak setuju', 'setuju', dan 'sangat setuju', dalam kuesioner terdapat lembaran identitas responden dan arahan mengenai cara menjawab, responden diwajibkan untuk memilih salah satu dari alternatif jawaban.

\section{Teknik Analisis Data}

Validitas merupakan tingkat kemampuan suatu alat ukur untuk mengukur apa yang seharusnya di ukur (Sugiyono, 2012). Dalam penelitian ini, instrumen yang dinyatakan valid dengan melihat hasil koefisien korelasi item total sebesar 0,20, jika item menyatakan tanda negatif (-) dan dibawah 0,20 item tersebut dinyatakan gugur dan tidak layak pakai (Nurgiyantoro, Gunawan, \& Marzuki, 2009). Pengukuran validitas ini menggunakan bantuan SPSS versi 17 for windows. Reliabilitas berasal dari kata reliability yang mempunyai asal kata rely dan ability. Bila digabungkan akan memiliki pemahaman tentang kepercayaan terhadap kemampuan alat ukur (Ghozali, 2006). Pada penelitian ini uji reliabilitas menggunakan alpha cronbach's dengan bantuan SPSS versi 17 for windows. Suatu alat ukur dinyatakan memiliki reliabilitas yang baik apabila skor alpha lebih besar dari 0,6 (Arikunto, 2006).

Metode analisis data menggunakan korelasi product moment dari Karl Pearson, dengan bantuan program SPSS versi 17 for windows. Analisis data ini digunakan untuk mengetahui kuatnya hubungan antara satu variabel bebas terhadap variabel terikat. Dalam melakukan analisis data, terdapat dua syarat yang harus dipenuhi, yaitu uji asumsi berupa uji normalitas dan uji linieritas dengan alat bantu perangkat lunak SPSS versi 17 (Sugiyono,2012). Uji normalitas dilakukan untuk mengetahui normal atau tidaknya sebaran skor variabel komunikasi interpersonal dan variabel keharmonisan pernikahan (Hadi, 2000). Pada uji normalitas ini digunakan uji statistik kolmogorov-smirnov, jika nilai signifikansi $(p>0,05)$ maka data dikatakan memiliki distribusi normal (Nurgiyantoro, Gunawan, \& Marzuki, 2009). Uji linieritas dilakukan untuk mengetahui apakah terdapat hubungan yang linier antara kedua variabel penelitian
(Sudjana, 2003). Pengujian pada penelitian pada dengan menggunakan compare means-test for linierity dengan pada taraf signifikansi 0,05 . Dua variabel dikatakan mempunyai hubungan yang linier bila signifikansi $(\mathrm{p}<0,05)$ (Nurgiyantoro, Gunawan, \& Marzuki, 2009).

\section{HASIL PENELITIAN}

Uji coba alat ukur dalam penelitian ini dilakukan terhadap responden penelitian, yaitu dengan kriteria inklusi istri yang bekerja, berusia 21-35 tahun atau dewasa awal, usia pernikahan 0-5 tahun dan berada di Denpasar. Uji coba ini dilakukan dengan menyebar skala kepada 60 orang dan dilaksanakan pada bulan November sampai Desember 2012. Data yang telah diperoleh pada saat uji coba alat ukur penelitian akan dianalisis untuk mengetahui validitas dan reliabilitas suatu alat ukur. Berdasakan hasil uji coba item skala komunikasi interpersonal yang terdiri dari 45 item diperoleh koefisien korelasi yang bergerak dari $-0,15$ hingga 0,472. (Nurgiyantoro, dkk. 2009) menyatakan bahwa instrumen dinyatakan valid dengan melihat hasil koefisien korelasi item total sebesar 0,20 , jika item menyatakan tanda negatif (-) dan dibawah 0,20 item tersebut dinyatakan gugur dan tidak layak pakai, sehingga terdapat 19 item yang gugur dan 26 item yang valid memiliki koefisien korelasi yang bergerak dari 0,213 hingga 0,541 . Hasil uji coba item pada skala keharmonisan pernikahan yang terdiri dari 30 item diperoleh koefisien korelasi yang bergerak dari 0,40 hingga 0,539 . Terdapat 12 item yang gugur dan 18 item yang valid memiliki koefisien korelasi yang bergerak dari 0,230 hingga 0,542 .

Berdasarkan hasil pengujian reliabilitas koefisien alpha $(\alpha)$ pada skala komunikasi interpersonal saat uji coba adalah 0,799, sedangkan hasil reliabilitas koefisien alpha $(\alpha)$ saat penelitian adalah 0,844. Pada skala keharmonisan pernikahan hasil reliabilitas koefisien alpha $(\alpha)$ saat uji coba adalah 0,767 , sedangkan hasil reliabilitas koefisien alpha $(\alpha)$ saat penelitian adalah 0,825 . Hasil tersebut menunjukkan bahwa alat ukur komunikasi interpersonal dan keharmonisan pernikahan dalam penelitian ini memiliki reliabilitas yang baik.

Berdasarkan hasil uji normalitas, diketahui bahwa sebaran data pada variabel komunikasi interpersonal memiliki nilai signifikasi dengan probabilitas (p) sebesar 0.709 dan pada varibel keharmonisan pernikahan memiliki nilai signifikasi dengan probabilitas (p) sebesar 0.309, kedua variabel tersebut memiliki nilai probabilitas diatas 0,05 $(p>0,05)$, sehingga menunjukkan bahwa kedua varibel berdistribusi normal. Pada hasil uji linieritas, diketahui bahwa terdapat hubungan yang linier antara variabel komunikasi interpersonal dengan variabel keharmonisan pernikahan, yaitu nilai signifikansi dengan probabilitas (p) sebesar 0,000 atau (p 
$<0,05)$, sehingga mununjukkan bahwa kedua variabel bersifat linier.

Setelah melalui uji asumsi, peneliti melakukan uji hipotesis untuk menjawab hipotesis secara empiris. Uji hipotesis dalam penelitian ini menggunakan teknik korelasi product moment dari Karl Pearson dengan menggunakan aplikasi SPSS versi 17.0 for windows, dengan taraf signifikansi 0,05 yang artinya bahwa kepercayaan terhadap kebenaran hipotesis adalah 95\%. Uji korelasi ini menggunakan uji korelasi 1 ekor (one-tailed) karena hipotesis pada penelitian ini berarah tunggal yang berarti arah hubungannya bersifat positif (Santoso, 2003). Hasil analisis yang diperoleh akan dijelaskan sebagai berikut :

Tabel 1

Hasil Uji Korelasi

\begin{tabular}{|l|l|}
\hline & TotalKI dan TotalKP \\
\hline $\begin{array}{l}\text { Product Moment (Pearson } \\
\text { Correlation }\end{array}$ & 0.649 \\
\hline Sig. (1-tailed) & 0.000 \\
\hline
\end{tabular}

Hasil analisis data menunjukkan korelasi antara variabel komunikasi interpersonal dan keharmonisan pernikahan, dengan nilai koefisien korelasi (r) yang diperoleh sebesar 0,649, menunjukkan bahwa adanya hubungan yang kuat antara variabel komunikasi interpersonal dan variabel keharmonisan pernikahan. Hasil analisis menunjukkan bahwa kedua variabel dalam penelitian memiliki hubungan yang searah yaitu bernilai positif, dimana apabila semakin tinggi skor komunikasi interpersonal maka akan mengakibatkan semakin tinggi pula skor pada keharmonisan pernikahan.

Dari korelasi variabel komunikasi interpersonal dan variabel keharmonisan pernikahan diperoleh angka probabilitas signifikansi $(p)=0,000$. Oleh karena probabilitas $(0,000)$ jauh lebih kecil dari 0,05 atau ( $\mathrm{p}<0,05)$, yang berarti bahwa Ho ditolak dan $\mathrm{Ha}$ diterima yang menyatakan bahwa ada hubungan positif antara komunikasi interpersonal pasutri dengan keharmonisan dalam pernikahan. Jadi, kesimpulannya adalah ada hubungan positif dan signifikan antara komunikasi interpersonal pasutri dengan keharmonisan dalam pernikahan.

Selanjutnya untuk menyatakan besar kecilnya sumbangan yang dapat diberikan dari variabel bebas (komunikasi interpersonal) terhadap variabel terikat (keharmonisan pernikahan) dapat ditentukan dengan rumus koefisien determinasi sebagai berikut :

$$
\mathrm{KD}=\left(\mathrm{r}^{2}\right) \times 100 \%
$$

Koefisien determinasi diperoleh dari mengkuadratkan nilai $r$ yaitu $(0,649)^{2} \times \quad 100 \%$ sehingga didapat hasil $\left(r^{2}\right)$ sebesar 0,422 yang menunjukkan pengertian bahwa variabel keharmonisan pernikahan dipengaruhi sebesar 42,2\% oleh variabel komunikasi interpersonal dan sisanya (100\% - 42,2\% $=57,8 \%$ ) dipengaruhi oleh faktor-faktor lain yang tidak diteliti dalam penelitian ini.

Peneliti melakukan analisis tambahan dengan menggolongkan subjek penelitian yang memiliki skor komunikasi interpersonal dan keharmonisan pernikahan dari yang paling tinggi hingga paling rendah. Penggolongan ini dilakukan dengan menggunakan rumus pengkategorian skor dari Azwar (2012).

Tabel 2

Kategorisasi Subjek pada Skala Komunikasi Interpersonal

\begin{tabular}{|l|l|l|l|}
\hline Skor & Kategori & Frekuensi & Persentase \\
\hline $\mathrm{x}<52$ & Rendah & 0 & $0 \%$ \\
\hline $52 \leq \mathrm{x}<78$ & Sedang & 34 & $30,9 \%$ \\
\hline $78 \leq \mathrm{x}$ & Tinggi & 76 & $69,1 \%$ \\
\hline Total & & 110 & $100 \%$ \\
\hline
\end{tabular}

Berdasarkan data diatas, dapat dilihat bahwa mayoritas subjek dalam penelitian ini termasuk dalam kategori tinggi yaitu sebesar $69,1 \%$ atau 76 orang. Hal in berarti bahwa subjek dalam penelitian ini memiliki komunikasi interpersonal yang efektif.

Tabel 3

Kategorisasi Subjek pada Skala Keharmonisan Pernikahan

\begin{tabular}{|c|c|c|c|}
\hline Skor & Kategori & Frekuensi & Persentase \\
\hline $\mathrm{X}<36$ & Rendah & 0 & $0 \%$ \\
\hline $36 \leq X<54$ & Sedang & 26 & $23,6 \%$ \\
\hline $54 \leq X$ & Tinggi & 84 & $76,4 \%$ \\
\hline \multicolumn{2}{|c|}{ Total } & 110 & $100 \%$ \\
\hline
\end{tabular}

Berdasarkan data diatas, dapat dilihat bahwa mayoritas subjek dalam penelitian ini termasuk dalam kategori tinggi yaitu sebesar $76,4 \%$ atau 84 orang. Hal ini berarti bahwa subjek dalam penelitian ini memiliki pernikahan yang harmonis.

\section{PEMBAHASAN DAN KESIMPULAN}

Berdasarkan hasil analisis data penelitian, maka hipotesis yang telah diajukan, yaitu ada hubungan positif antara komunikasi interpersonal pasutri dengan keharmonisan dalam pernikahan diterima. Hasil penelitian menunjukkan adanya hubungan yang signifikan antara komunikasi interpersonal dengan keharmonisan pernikahan. Hal ini dapat dilihat dari hasil uji korelasi product moment dari Karl Pearson dengan nilai $(\mathrm{r})$ sebesar 0,649 dengan $\mathrm{p}=0,000(\mathrm{p}<$ 0,05), artinya jika terjadi peningkatan pada variabel komunikasi interpersonal maka akan terjadi peningkatan juga terhadap variabel keharmonisan pernikahan. 


\section{N. R. DEWI DAN H.SUDHANA}

Harmonis tidaknya sebuah pernikahan tergantung dari kondisi hubungan interpersonal pasangan suami istri, hubungan tersebut dapat terjalin dengan baik melalui komunikasi yang efektif antara suami dan istri. Seperti yang dikemukakan oleh Surya (2001) keharmonisan keluarga merupakan suatu perwujudan kondisi kualitas hubungan interpersonal baik inter maupun antar keluarga. Hubungan interpersonal merupakan awal dari keharmonisan. Hal ini mengandung arti bahwa keharmonisan akan sulit terwujud tanpa adanya hubungan interpersonal, baik dalam keluarga maupun antar keluarga. Begitu pula untuk mewujudkan suatu pernikahan yang harmonis akan sulit terwujud tanpa adanya hubungan interpersonal yang baik antara suami dan istri. Agar suasana hubungan yang baik dapat terwujud diperlukan suasana yang hangat, penuh pengertian, penuh kasih sayang satu dengan lainnya agar dapat menimbulkan suasana yang akrab dan ceria diantara suami dan istri. Dasar terciptanya suasana hubungan ini adalah terciptanya komunikasi yang efektif diantara suami dan istri.

Pasangan suami istri yang mampu melakukan komunikasi interpersonal dengan efektif ditandai dengan adanya hubungan interpersonal yang baik pula antara kedua belah pihak yaitu suami dan istri. Tailor (dalam Rakhmat, 1996) menjelaskan bahwa hubungan interpersonal tersebut tidak hanya ditentukan oleh sering atau tidaknya individu melakukan komunikasi, akan tetapi ditentukan juga oleh mutu dari komunikasi tersebut. Komunikasi yang baik adalah komunikasi yang efektif, yang ditunjukkan dari lima sikap positif dengan ciri adanya rasa saling terbuka, empati, saling mendukung, sikap positif dan kesetaraan (Devito, 1997). Apabila pasangan suami istri saling menunjukkan sikap yang positif terhadap pasangannya maka komunikasi interpersonal dapat berjalan secara efektif. Terciptanya komunikasi yang efektif diantara suami istri membuat hubungan interpersonal menjadi baik sehingga dapat terwujudnya keharmonisan dalam pernikahan yang ditunjukkan dengan adanya rasa saling mengerti, saling menerima, saling menghargai, saling percaya dan saling mencintai diantara suami dan istri (Daradjat dalam Hisbullah, 2007). Hal tersebut menunjukkan bahwa pasangan suami istri yang mampu bersikap positif dalam melakukan komunikasi interpersonal efektif dapat mendukung terwujudnya keharmonisan dalam pernikahan. Sebaliknya, jika pasangan suami istri menunjukkan sikap negatif seperti saling curiga terhadap pasangannya maka hubungan interpersonalnya menjadi renggang dan mengakibatkan komunikasi interpersonal antara suami dan istri menjadi tidak efektif (Tailor dalam Rakhmat, 1996).

Berdasarkan hasil yang diperoleh dari penelitian ini, maka komunikasi interpersonal pasutri diidentifikasi sebagai faktor yang memberikan pengaruh terhadap keharmonisan pernikahan. Sumbangan efektif komunikasi interpersonal pasutri terhadap keharmonisan pernikahan sebesar $42,2 \%$, namun komunikasi interpersonal bukanlah satu-satunya faktor yang dapat mempengaruhi keharmonisan pernikahan. Masih ada $57,8 \%$ faktor-faktor lain yang mempengaruhi yang tidak diteliti dalam penelitian ini.

Pada deskripsi data penelitian tampak bahwa pada variabel komunikasi interpersonal diperoleh mean teorietis sebesar 65 yang lebih kecil daripada mean empiris yang sebesar 82,27. Hal tersebut menunjukkan bahwa rata-rata subjek dalam penelitian ini memiliki kualitas komunikasi interpersonal yang efektif. Pada variabel keharmonisan pernikahan diperoleh mean teorietis sebesar 45 yang lebih kecil daripada mean empiris yang sebesar 58,23. Hal tersebut menunjukkan bahwa rata-rata subjek dalam penelitian ini memiliki pernikahan yang harmonis.

Dari hasil kategorisasi skor penelitian pada skala komunikasi interpersonal, terlihat bahwa mayoritas subjek dalam penelitian ini yaitu wanita atau istri yang bekerja termasuk dalam kategori tinggi yaitu sebesar $69,1 \%$ atau 76 orang. Hal in berarti bahwa subjek dalam penelitian ini memiliki komunikasi interpersonal yang efektif. Hasil dari kategorisasi skor pada skala keharmonisan pernikahan, terlihat bahwa mayoritas subjek dalam penelitian ini termasuk dalam kategori tinggi yaitu sebesar $76,4 \%$ atau 84 orang. Hal ini berarti bahwa subjek dalam penelitian ini memiliki pernikahan yang harmonis. Dari hasil kategori skor pada kedua variabel tersebut dapat disimpulkan bahwa subjek dalam penelitian ini termasuk dalam kategori tinggi yang berarti subjek dalam penelitian ini menunjukkan kualitas komunikasi interpersonal yang efektif dan memiliki pernikahan yang harmonis.

Hal ini menunjukkan bahwa tidak jarang wanita yang bekerja bisa sukses dalam membina rumah tangga yang harmonis (Surya, 2001). Karir yang dimiliki istri dapat menunjang kebahagiaan dan kemajuan bagi rumah tangganya. Secara ekonomi, dengan bekerja dapat membantu kelangsungan hidup keluarga secara finansial. Secara sosial, kaum wanita dapat mengabdikan dirinya untuk kepentingan sosial, dimana lingkup pergaulan sosial menjadi lebih luas. Serta secara psikologis, dengan bekerja wanita dapat memperoleh kepuasan pribadi yang dapat menunjang kebahagian. Selanjutnya, Surya (2001) menjelaskan bahwa salah satu cara yang dapat dilakukan wanita yang bekerja atau berkarir untuk bisa sukses dalam membangun rumah tangga yang harmonis adalah dengan melakukan penyesuaian antara diri dengan pekerjaan, yang disertai oleh dukungan dari suami dan anggota keluarga untuk bisa menjaga keseimbangan antara pekerjaan dan urusan rumah tangga. Dukungan tersebut dapat dikembangkan melalui komunikasi interpersonal yang efektif antara suami dan istri.

Berdasarkan hasil analisis dengan menggunakan teknik product moment yang telah dilakukan, peneliti telah mencapai tujuan penelitian yaitu ada hubungan positif antara komunikasi interpersonal pasutri dengan keharmonisan 
pernikahan. Hal ini menandakan bahwa apabila komunikasi interpersonal pasutri semakin efektif maka pernikahannya semakin harmonis.

Adapun saran-saran yang dapat diberikan peneliti berdasarkan dari hasil penelitian ini yaitu saran praktis dan saran bagi peneliti selanjutnya. Saran praktis antara lain yaitu, bagi pasangan suami istri yang sama-sama bekerja agar lebih sering meluangkan waktu untuk bertemu dan saling berkomunikasi secara intim dengan pasangannya, untuk menghindari munculnya perasaan negatif seperti rasa saling curiga terhadap pasangan yang dapat menimbulkan konflik. Dan sebaiknya suami bisa memahami dan saling bekerjasama dalam mengerjakan pekerjaan rumah tangga sehingga dapat mengurangi beban istri, dengan adanya kerjasama yang baik didalam rumah tangga diharapkan dapat mewujudkan pernikahan yang harmonis. Selanjutnya saran praktis bagi peneliti selanjutnya yang tertarik untuk melihat hubungan antara komunikasi interpersonal pasutri dengan keharmonisan pernikahan, diharapkan dapat menyempurnakan penelitian ini dengan menambah faktor-faktor lainnya yang berpengaruh terhadap keharmonisan pernikahan. Faktor-faktor lain yang dapat mempengaruhi keharmonisan pernikahan seperti faktor psikologis, kesehatan, seksual, sosial-ekonomi, dan keluarga.

\section{DAFTAR PUSTAKA}

Agustia, Emy. (2010). Usia-usia pernikahan rentan masalah. Retrieved Januari 12, 2013, from http://female.kompas.com/read/2010/01/23/09432140/usia_usia. pernikahan.rentan.masalah.

Anonim. (2008). Sumber konflik suami istri. Retrieved Januari 05, 2013, from http://health.kompas.com/read/2008/10/11/10053832/8.Sumber. Konflik.Suami.Istri.

Arikunto, Suharsimi. (2006). Prosedur penelitian suatu pendekatan praktik. Jakarta: PT Remaja Cipta.

Azwar, Saifuddin. (2004). Reliabilitas dan validitas. Yogjakarta: Penerbit Pustaka Pelajar.

Azwar, Saifuddin. (2012). Penyusunan skala psikologi edisi kedua. Yogjakarta: Penerbit Pustaka Pelajar.

Boediono \& Koster, W. (2004). Teori dan aplikasi statistika dan probabilitas. Bandung: PT Remaja Rosdakarya.

Devito, Joseph. (1997). Komunikasi antar manusia (terjemahan). Jakarta: Professional Books.

Gregory, R.J. (2000). Psychological testing : history, principles and applications. Boston: Allyn\&Bacon.

Gustin, Y.M. (2009). Komunikasi interpersonal suami istri dalam penyelesaian masalah rumah tangga. skripsi tidak diterbitkan.
Hadi, S. (2000). Metodologi research. Yogjakarta: Andi.

Hardjana, A.M. (2003). Komunikasi intrapersonal \& interpersonal. Kanisius, Jakarta.

Hidayat, L. (2007). Korelasi antara citra badan dengan komunikasi interpersonal pada remaja di smun 1 gondang wetan pasuruan. Skripsi Fakultas Psikologi Universitas Islam Negeri (UIN), Malang.

Higgins J.E., Kleinbaum. A.P., \& Miller P. (1985). Design methodology to randomized clinical trials : Family health internasional. North Carolina 27709 USA: Researsch Triangle Park.

Hisbullah, M. (2007). Pengaruh tingkat kecerdasan spiritual terhadap keharmonisan rumah tangga pada suami-istri di desa selokbesuki kecamatan sukodono kabupaten lumajang. Skripsi Fakultas Psikologi Universitas Islam Negeri (UIN), Malang.

Husein, Umar. (2002). Metode riset bisnis. Jakarta: PT. Gramedia Pustaka Utama.

Ghozali, I. (2006). Aplikasi analisis multivariate dengan program spss. Semarang: Badan Penerbit Universitas Diponegoro.

Ismawati. (2012). Perilaku komunikasi istri pelayar dalam membina keharmonisan rumah tangga di kecamatan suli, kabupaten luwu. skripsi tidak diterbitkan.

Muhammad, Arni. (2005). Komunikasi organisasi. Jakarta: Bumi Aksara.

Murcahya, Ardhianto. (2010). Dinamika psikologis pengambilan keputusan untuk menikah dini. Skripsi Universitas Muhammadiyah, Surakarta.

Nugroho, S.S. (2007). Hubungan antara persepsi terhadap komunikasi keluarga dengan konflik peran ibu bekerja di RS panti wilasa "citarum" semarang. Skripsi Universitas Diponogoro.

Nurgiyantoro, B., Gunawan, \& Marzuki. (2009). Statistik terapan ( untuk penelitian ilmu-ilmu sosial). Yogjakarta: Gadjah Mada University Press.

Pertiwi, Sarri. (2006). Hubungan antara harga diri dan efektivitas komunikasi suami istri dengan kecemasan suami yang istrinya berpenghasilan lebih tinggi. skripsi tidak diterbitkan.

Prakoso, A. (2008). Pengertian komunikasi. Retrieved Desember 21, 2012, from: http://adiprakoso.blogspot.com/2008/09/pengertiankomunikasi.html.

Rakhmat, Jalaludin. (1996). Psikologi komunikasi. Bandung: PT Remaja Rosdakarya.

Santoso, Singgih. (2002). SPSS statistik parametrik. Jakarta: Elek Media Komputindo.

Saputra, A. (2011). Tingkat perceraian di Indonesia meningkat. Retrieved September 26, 2012, 
fromhttp://news.detik.com/read/2011/08/04/124446/1696402/10 /tingkat-perceraian-di-indonesia-meningkat.html.

Sudjana. (2003). Metoda statistika. Bandung: Tarsito

Sugiyo. (2005). Komunikasi antarpribadi. Semarang: UNNES Press. Sugiyono. (2004). Metode penelitian bisnis. Bandung: CV Alfabeta. Sugiyono. (2012). Statistika untuk penelitian. Bandung: CV Alfabeta. Sunarto dan Riduwan. (2009). Pengantar statistik. Bandung: CV Alfabeta.

Suranto, A.W. (2011). Komunikasi interpersonal. Yogjakarta: Graha Ilmu.

Surya, Mohammad. (2001). Bina keluarga. Semarang: CV Aneka Ilmu.

Suryanto, C. A. (2006). Pola penyesuaian perkawinan pada periode awal. Jurnal Fakultas Psikologi Universitas Airlangga, 8, 3.

Vembry, Rezky. (2012). Kepuasan perkawinan pada istri dengan suami sebagai pelaku kekerasan dalam rumah tangga. Skripsi Universitas Gunadarma.

Wardhani, N. A. (2012). Self disclosure dan kepuasan perkawinan pada istri di usia awal pernikahan. Jurnal Ilmiah Mahasiswa Universitas Surabaya , 1, 3-4. 